\title{
Lack of stimulation of relaxin secretion in lactating sows by suckling in vivo or by oxytocin in vitro
}

\author{
M. G. Hunter ${ }^{1}$, P. Denning-Kendall ${ }^{2}$, M. I. Boulton ${ }^{1}$, F. De Rensis*, \\ M. L. Wild ${ }^{2}$ and G. R. Foxcroft* \\ ${ }^{1}$ AFRC Research Group on Hormones and Farm Animal Reproduction, University of Nottingham, \\ Faculty of Agricultural and Food Sciences, Loughborough, Leics., LE12 5RD, UK; and \\ ${ }^{2}$ Department of Anatomy, School of Medical Sciences, University of Bristol, Bristol BS8 ITD, UK
}

\begin{abstract}
Summary. After parturition, eight sows were zero weaned by removing all piglets $6 \mathrm{~h}$ after birth; a further 18 sows suckled at least ten piglets each. Blood samples were collected on Day 4 after zero weaning or on Days 4, 14 and 21 of lactation and the sampling frequency increased during suckling bouts. Ovaries were recovered from sows on these days and corpora lutea were either extracted for estimation of relaxin and progesterone concentration, fixed for immunohistochemical analysis or incubated in vitro in the presence or absence of luteinizing hormone $(\mathrm{LH})$ or oxytocin. Luteal weight and progesterone were higher in the zero-weaned sows than in lactating sows $(P<0.05$ and $<0.001$, respectively); relaxin content was below detection by Day 14 . This was supported by immunohistochemical staining for relaxin, which showed limited immunostaining in zero-weaned and Day 4 sows, but none in the tissue recovered on Days 14 and 21 , which showed typical signs of regression. Secretion of progesterone and relaxin by luteal tissue in vitro was highest in zero-weaned sows $(P<0.05)$, decreased as lactation progressed and neither LH nor oxytocin had any significant effect. Concentrations of plasma relaxin were all $<0.2 \mathrm{ng} / \mathrm{ml}$ in three of the four zero-weaned and Day-4-suckled sows assayed; there was no detectable increase during suckling bouts. It was concluded that during lactation the old corpus luteum of pregnancy is not able to release relaxin in response to suckling in vivo or to oxytocin treatment in vitro.
\end{abstract}

Ke.words: relaxin; suckling; oxytocin; lactation; pig

\section{Introduction}

The corpus luteum in pregnant pigs synthesizes large quantities of the peptide hormone relaxin. This is released slowly throughout most of gestation, but concentrations in the peripheral circulation rise during the last few days of pregnancy, culminating in a marked prepartum surge. This is followed by a precipitous decline, so that, by the onset of delivery, concentrations in the blood are already low (Sherwood et al., 1975; Anderson et al., 1983; Wathes et al., 1989). The precise regulation of release of ovarian relaxin is uncertain, although prostaglandins F-2 $\alpha$ (Nara et al., 1982) and E-2 (Taylor \& Clark, 1987) as well as luteinizing hormone (LH) (Gordon \& Sherwood, 1982) and human chorionic gonadotrophin (Taylor \& Clark, 1987) have all been reported to stimulate release of relaxin in vivo and/or in vitro. It has also been suggested that suckling is a stimulus for release of relaxin from the old corpus luteum during lactation (Afele et al., 1979) and that this action may be mediated by oxytocin (Whitely et al., 1985). However, these studies are in conflict with others that have been unable to demonstrate any effect of oxytocin on release of relaxin either in vivo (Sherwood et al., 1981; Kendall et al., 1983) or in vitro (Taylor \& Clark, 1987). 
The removal of piglets from sows at, or within, a few hours of birth (zero-weaning) has been studied primarily with the aim of increasing the productivity of sows by eliminating the lactational period. As the zero-weaned sow is no longer suckled, zero weaning provides the opportunity to study the pattern of release of relaxin in the early post-partum period in the absence of the suckling stimulus and its associated release of oxytocin.

The present study investigated whether suckling and oxytocin are stimuli for release of relaxin in lactating sows and whether the source is the old corpus luteum of pregnancy. The secretion of relaxin was studied in vivo in sows during suckling on Days 14 and 21, and on Day 4 of lactation and zero weaning; and by challenging luteal tissue from the same sows with oxytocin in vitro.

\section{Materials and Methods}

Animals and sampling. Twenty-six primiparous Landrace $\times$ Large White sows from the herd at University of Nottingham were used, with a mean ( \pm s.e.m.) live weight of $170 \pm 5 \cdot 3 \mathrm{~kg}$ at farrowing. Indwelling jugular cannulae were inserted surgically 4 days before expected parturition, to allow stress-free sampling of suckling sows without restraint or physical interference. After parturition, eight sows were zero weaned by removing all piglets $6 \mathrm{~h}$ after the birth of the last piglet; the other 18 sows suckled at least ten piglets each. Blood samples $(2.5 \mathrm{ml})$ were taken at 5 -min intervals between 08:00 and 09:00 h on Day 4 after zero weaning $(n=8)$ or on Day $4(n=11), 14(n=10)$ or $21(n=3)$ of lactation. At the onset of any suckling bouts during this period, the sampling frequency was increased to $30 \mathrm{~s}$ and continued for 5 min making a total of 13 samples collected during a suckling bout. Frequent samples were obtained during at least one suckling bout in each sow, during which normal sow and piglet behaviour and successful milk let-down were considered to have occurred. Ovaries were recovered from the sows by either surgery or slaughter on Day 4 after zero weaning $(n=8)$, or on Days $4(n=5), 14(n=7)$ or $21(n=6)$ of lactation and transferred to the laboratory within $10 \mathrm{~min}$.

Ovarian tissue. All corpora lutea were carefully dissected from the ovaries and individually weighed. Four corpora lutea from each sow were sliced and tissue pieces $(5-20 \mathrm{mg})$ were incubated for $2 \mathrm{~h}$ in a shaking water bath at $37^{\circ} \mathrm{C}$ in $2 \mathrm{ml}$ of Basal Medium Eagle (BME: Flow Laboratories, Irvine, UK) containing $0 \cdot 1 \%$ bovine serum albumin (BSA, Fraction V, Sigma Chemical Co., Poole, Dorset, UK) alone, plus luteinizing hormone ( $100 \mathrm{ng} \mathrm{pLH} / \mathrm{ml}$; Institute Voor Veeteeltkundig Onderzoek; $0.77 \times$ NIH-LH.S1) or plus oxytocin $(0.01 \mathrm{iu} / \mathrm{ml}$ : Sigma Chemical, Co., Poole, Dorset, UK). The doses of LH and oxytocin used were those which have been previously demonstrated to have a significant effect on porcine luteal tissue in vitro (Przala et al., 1986). Quadruplicate incubations were carried out for luteal tissue from zero-weaned and Day 4 sows, but only singly for luteal tissue from Day 14 and Day 21 sows, because of the reduced size of the regressing corpora lutea in these animals. Incubations were carried out in 7-ml polypropylene bijoux containers (Flow Laboratories, Irvine, UK), which were filled with $95 \% \mathrm{O}_{2}: 5 \% \mathrm{CO}_{2}$ for $10 \mathrm{~s}$ before being sealed and incubated. At the end of the incubation period, the tissue was weighed and the media were stored at $-20^{\circ} \mathrm{C}$ until assayed for progesterone and relaxin. Halves of three corpora lutea were immediately placed in fixative $(2.5 \%$ glutaraldehyde, $4 \%$ paraformaldehyde and $\sim 0.1 \mathrm{~mol}$ sodium cacodylate $/ 1, \mathrm{pH} 7.4$ ) after dissection for subsequent immunohistochemical localization of relaxin. One half of each of the remaining corpora lutea was weighed and stored in liquid nitrogen until relaxin content was measured; the other halves were stored at $-20^{\circ} \mathrm{C}$ until progesterone content was measured.

Immunohistochemistry. After 1 week in fixative at $4^{\circ} \mathrm{C}$, tissues were dehydrated and embedded in Paraplast (Sherwood Medical, St Louis, MO, USA). Tissue sections of $7 \mu \mathrm{m}$ were mounted on slides coated with chrome alum and gelatin. Sections were immunostained for relaxin using the peroxidase antiperoxidase staining method described by Denning-Kendall et al. (1989). After dewaxing, rehydration and washing, the sections were incubated for $20 \mathrm{~min}$ at room temperature with undiluted normal ovine serum. After removal of excess serum, the sections were incubated with antiserum $1083(1: 500 \mathrm{v} / \mathrm{v})$ diluted in Triton buffer for $1 \mathrm{~h}$ at room temperature followed by incubation for $16 \mathrm{~h}$ at $4{ }^{\circ} \mathrm{C}$ in a moist chamber. Incubations with the second antibody (ovine anti-rabbit) at a dilution of $1: 15$ and rabbit PAP (UCB Bioproducts, Braine L'Alleud, Belgium) at a dilution of $1: 100$, were for $1 \mathrm{~h}$ each at room temperature. Peroxidase-dependent staining was developed by incubation of slides with 3,3-diaminobenzidine dissolved at $0.5 \mathrm{mg} / \mathrm{ml}$ in $0.05 \mathrm{~mol}$ Tris $/ 1$, $\mathrm{pH} 7.6$, containing $0.03 \%(\mathrm{v} / \mathrm{v})$ hydrogen peroxide.

Tissue extraction. The half corpora lutea collected for relaxin measurement from zero-weaned and Day 4 sows were extracted individually, whereas corpora lutea halves from Day 14 and Day 21 sows were pooled for extraction using the method of Walsh \& Niall (1980) as described by Denning-Kendall et al. (1989). The average recovery of relaxin was $76 \%$. All corpora lutea halves were extracted for progesterone content as described by Hunter et al. (1988).

Radioimmunoassays. Lyophilized extracts of luteal tissue were reconstituted in $1 \mathrm{ml} 0.05$ mol sodium barbitone buffer $/ 1, \mathrm{pH} 8 \cdot 5$, containing $0.5 \%$ bovine serum albumin and all samples were measured in the same assay for relaxin. The assay for pig relaxin was that described by Taverne et al. (1982) and Evans et al. (1983) and modified by Denning- 
Kendall et al. (1989). NIH-RXN-PI was used as the standard and the tracer was carboxy methyl (CM)-y relaxin which eluted from CM-cellulose at a position close to that of the CM- $\beta$ relaxin used by Sherwood \& O'Byrne (1974). It had an activity of 2000-3000 guinea-pig units (G.P.U.)/mg in the mouse pubic symphysis bioassay of Steinetz $\mathrm{et} \mathrm{al}$. (1960). For production of ${ }^{125} \mathrm{I}$ relaxin, $25 \mu \mathrm{g} \mathrm{CM}-\mathrm{y}$ relaxin was reacted with $0.75 \mu \mathrm{g}$ of Bolton \& Hunter reagent (Kwok et al., 1976) before iodination with $1 \mathrm{mCi}$ of ${ }^{125} \mathrm{I}$ by the chloramine $\mathrm{T}$ method. The antiserum used was 1083 , which was raised against heterologous $C M-a, C M-a^{1}$ and $C M-\beta$ relaxin (Sherwood $e t$ al., 1975). The sensitivity of the assay was $30 \mathrm{pg} /$ tube, and the intra-assay coefficient of variation was $7.6 \%$. All values are given as $\mu \mathrm{g}$ equivalents of $\mathrm{NIH-R}$ XN-Pl pig relaxin standard. Plasma and media samples were assayed for relaxin as described above, standards containing either $100 \mu \mathrm{l}$ of prepubertal porcine serum or $100 \mu \mathrm{l} \mathrm{media.} \mathrm{The} \mathrm{sensitivity} \mathrm{of} \mathrm{these} \mathrm{assays} \mathrm{was} 16 \mathrm{pg} / \mathrm{tube}$ and inter- and intra-assay coefficients of variation were 14.4 and $4.3 \%$, respectively.

Progesterone concentrations in media and ethanolic tissue extracts were measured directly using the method described by Hunter $e t$ al. (1988). Sensitivity of these assays was $0.32 \mathrm{ng} / \mathrm{ml}$ and inter- and intra-assay coefficients of variation were 19 and $13 \%$, respectively, for the media samples and 13 and $12 \%$, respectively, for the tissue extracts.

Statistical analyses. Comparisons between the four groups of sows (zero weaned, Day 4, Day 14 and Day 21) in terms of luteal weight, progesterone in tissue or media, and relaxin in tissue or media were carried out by analysis of variance and the significance of difference between means was determined by the test for least-significant difference.

\section{Results}

\section{Luteal tissue}

The mean number of corpora lutea was similar in all groups (Table 1), but the luteal wet weight was significantly greater at Day $4(P<0.05)$ in zero-weaned sows than in control sows, which in turn had significantly heavier corpora lutea $(P<0.01)$ than those on Day 14 and Day 21 in lactating sows. Suckling in the early post-partum period had an even more immediate effect and reduced luteal progesterone content in suckled compared with zero-weaned sows by Day 4 $(P<0.001)$. Several of the corpora lutea recovered on Day 21 had progesterone concentrations below the limit of sensitivity of the assay. The concentration of relaxin in the luteal tissue was variable and hence not significantly different between zero-weaned and control sows on Day 4; it was $<1 \mathrm{ng} / \mathrm{mg}$ in the pools of corpora lutea from Day 14 and Day 21 sows.

Table 1. Characteristics of corpora lutea recovered from zero-weaned sows on Day 4 $(n=8)$ and lactating sows on Days $4(n=5), 14(n=7)$ and $21(n=6)$ post-partum

\begin{tabular}{|c|c|c|c|c|c|}
\hline & Zero weaned & & Lactating & & \\
\hline Day post-partum & 4 & 4 & 14 & 21 & s.e.d.* \\
\hline Mean number of corpora lutea/sow & $14 \cdot 8$ & $13 \cdot 2$ & $14 \cdot 4$ & $13 \cdot 0$ & $1 \cdot 0$ \\
\hline Mean wet weight (mg) & $193^{a}$ & $151^{\mathrm{b}}$ & $38^{\mathrm{c}}$ & $31^{\mathrm{c}}$ & $9 \cdot 6$ \\
\hline $\begin{array}{l}\text { Mean progesterone concentration } \\
\text { (ng/mg tissue) }\end{array}$ & $3 \cdot 58^{a}$ & $0.25^{b}$ & $0 \cdot 30^{\mathrm{b}}$ & $0 \cdot 28^{\mathrm{b}}$ & 0.71 \\
\hline $\begin{array}{l}\text { Mean relaxin concentration } \\
(\mathrm{ng} / \mathrm{mg} \text { tissue })\end{array}$ & $25 \cdot 2$ & $17 \cdot 8$ & $<1$ & $<1$ & $7 \cdot 8$ \\
\hline
\end{tabular}

Overall, LH and oxytocin had no significant effect on the secretion of either progesterone or relaxin when groups of sows were considered together or separately (Fig. 1). Luteal tissue from zero-weaned sows on Day 4 secreted significantly more progesterone $(P<0.001)$ and relaxin $(P<0.05)$ in vitro than tissue from nursing sows on the same day. Relaxin concentrations in media after incubation of tissue for Day 21 sows were $<0 \cdot 2 \mathrm{ng} / \mathrm{mg} / \mathrm{h}$.

\section{Immunohistochemistry}

There was some immunoreactivity in corpora lutea recovered from sows on Day 4 and this appeared to be more intense in the zero-weaned sow (Fig. 2b,c). On Days 14 and 21 there was 

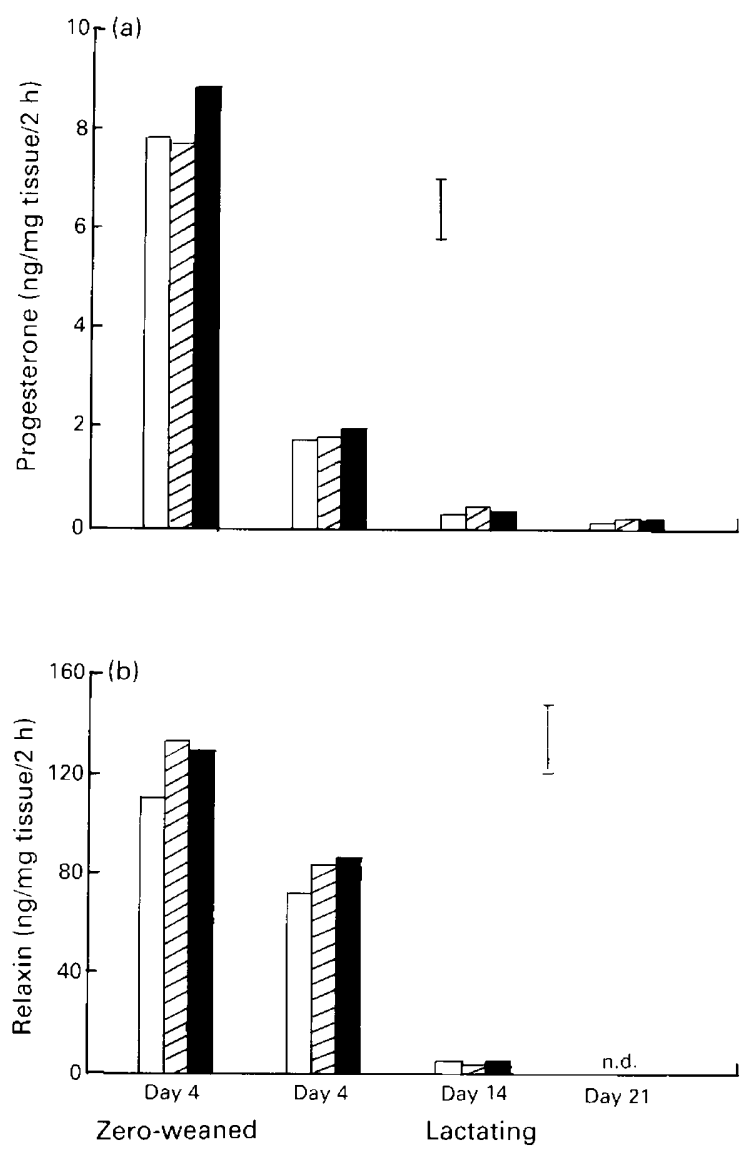

Fig. 1. Mean (a) progesterone and (b) relaxin released in vitro by tissue pieces from corpora lutea recovered from zero-weaned sows $(n=8)$ and lactating sows on Days $4(n=5), 14(n=$ 7) and $21(n=6)$ under control conditions $(\square)$ or in the presence of $100 \mathrm{ng}$ luteinizing hormone $/ \mathrm{ml}(\mathbb{C})$ or $0 \cdot 01$ i.u. oxytocin $/ \mathrm{ml}(\boldsymbol{Q})$. Vertical bars represent standard error of difference for comparing between-treatment means.

no detectable immunostaining in either of the sows investigated. The staining from each sow studied was quantified as: Day 31 of pregnancy $(+++++)$; zero-weaned $(++)$; Day 4 of lactation $(+)$; and Day 14 of lactation $(0)$, where $(+)$ indicates positive staining. Examination of luteal tissue stained with haematoxylin and eosin confirmed a typical pattern of luteal regression, with pycnotic nuclei, elongation of large luteal cells and invasion of connective tissues, particularly on Days 14 and 21.

\section{Plasma relaxin}

In three of the four zero-weaned sows from which blood samples were assayed, the concentrations of plasma relaxin were all $<0.2 \mathrm{ng} / \mathrm{ml}(n=33$ samples per sow). In the fourth animal, concentrations were above detection, but had a maximum value of only $0.33 \mathrm{ng} / \mathrm{ml}$. Of the four suckled animals from which Day 4 samples were assayed, three had $<0.2 \mathrm{ng}$ relaxin $/ \mathrm{ml}$. In the fourth animal, occasional samples were above the limit of sensitivity, with values of $0.22 \mathrm{ng} / \mathrm{ml}$; all the samples obtained from this animal during two suckling bouts were $<0.2 \mathrm{ng} / \mathrm{ml}$ except for two samples that had values of 0.22 and $0.24 \mathrm{ng} / \mathrm{ml}$. Since relaxin was undetectable in the majority of Day 4 plasma samples and in all Day 14 and Day 21 luteal tissue samples, relaxin was measured in 

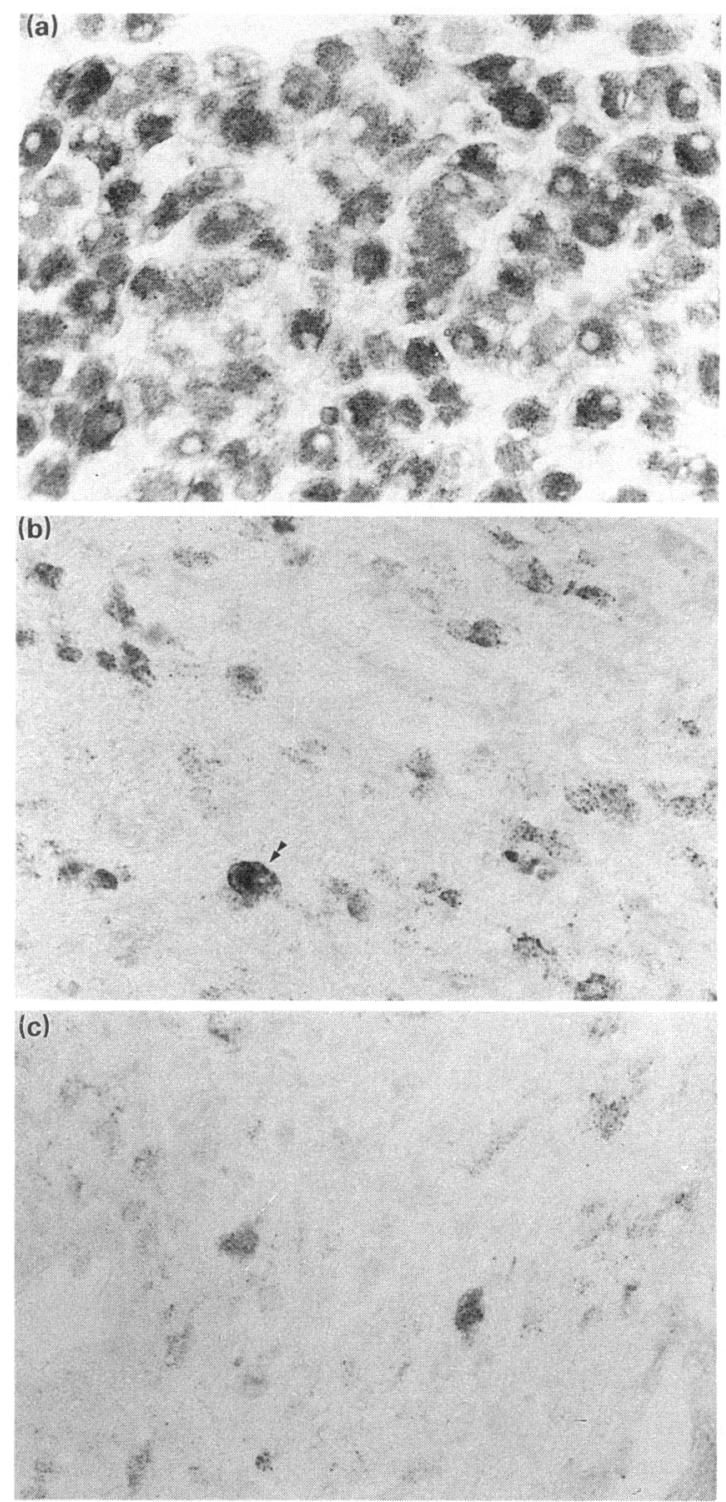

Fig. 2. Immunostaining of relaxin in a corpus luteum (a) on Day 31 of pregnancy; large luteal cells are rounded with clear nuclei and nearly all stain intensely; and (b) from a zero-weaned sow: the regressing tissue has lost much of its relaxin, although an occasional rounded large cell is seen (arrow); and (c) on Day 4 post partum of a nursing sow. Relaxin staining is less intense than in samples from the zero-weaned sow and cell boundaries are more disrupted, suggesting more rapid regression; all $\times 378$.

plasma of only one Day 14 sow, and again they were all $<0.2 \mathrm{ng} / \mathrm{ml}$, including those collected during two suckling bouts.

\section{Discussion}

The results of the present study are in contrast to the observations of Whitely et al. (1985) and Afele et al. (1979), who suggested that concentrations of circulating relaxin increased with suckling or 
administration of oxytocin in lactating sows and that the source of the relaxin was the old corpus luteum of pregnancy. Similar results were reported at various stages of lactation from Day 6 to Day 33. The present results indicate that the corpus luteum of lactation has extremely limited function, even by Day 4, in terms of concentrations and secretion of progesterone and relaxin, and even less on Days 14 and 21. Several findings suggest that the corpora lutea (CL) were regressing and thus unlikely to respond to any stimulus. First, even by Day 4 , the weight of the corpora lutea recovered was considerably less than the weights reported during the cycle and pregnancy (Rao \& Edgerton, 1984; Hunter \& Wiesak, 1990). In the suckled sows, concentration and secretion of progesterone and relaxin by luteal tissue in vitro declined rapidly during early lactation and the tissue did not respond at any time to LH or oxytocin. A study by Anderson et al. (1973) also found low concentrations of 53 and $3 \mathrm{ng}$ relaxin/g in CL on Days 9 and 21 of lactation, respectively, compared with $2000 \mu \mathrm{g}$ relaxin/g on Day 100 of pregnancy. The immunohistochemical staining supported the relaxin results, a few cells showing reactivity on Day 4, but none by Day 14 despite the use of a very sensitive technique. Furthermore, the appearance of the corpora lutea was typical of regressing tissue with pycnotic nuclei and ingrowths of connective tissue.

Anderson et al. (1983) reported that rapid luteal regression was detectable ultrastructurally after parturition and that cytoplasmic granules containing relaxin disappeared. Similarly, an immunohistochemical study by Bagnell et al. (1987b) of luteal relaxin during lactation showed staining on Day 2 of lactation, but a reduction in the size and number of cells containing relaxin by Day 8 . The relaxin-positive cells appeared spindle-shaped and reduced in size. Further investigation of gene expression for relaxin in the sow corpus luteum demonstrated that, although the message for relaxin was still detectable on Day 2, relaxin concentration was lower than during the cycle and pregnancy (Bagnell et al., 1990). In the present study, concentrations of plasma relaxin were virtually undetectable even at Day 4 and showed no increase during suckling. It is unlikely that inappropriate sampling could account for this, as sampling frequency was increased to every $30 \mathrm{~s}$ during suckling and several of the sows were sampled during more than one suckling period. The sows in this study were accustomed to continuous frequent sampling by the time samples were drawn for relaxin analysis on Day 4 , and stress-induced inhibition of milk ejection was unlikely. Although precise grunting patterns were not recorded and (for reasons of the blood volume required at $30 \mathrm{~s}$ intervals) changes in plasma oxytocin were not monitored, the pattern of piglet behaviour (intense nuzzling followed by intensive suckling as milk let-down occurred) indicated successful milk-ejection during sampling. Similarly, the sensitivity of the assay was well below the peak concentrations reported by Afele et al. (1979) and Whitely et al. (1985). The pattern of relaxin release in these two papers is also unlikely, as the majority of peaks apparently lasted less than $1 \mathrm{~min}$, reaching values well above baseline, but the half-life of relaxin in blood has been estimated at $\sim 20 \mathrm{~min}$ (Sherwood et al., 1980). Both Sherwood et al. (1981) and Kendall et al. (1983) were also unable to confirm a relaxin response to suckling.

The advantage of the present study over those described above is that both an in-vivo and invitro approach were used in the same animals. Thus, as well as the finding that relaxin in plasma was low, it was also demonstrated that the luteal content and secretion during incubation was barely detectable, particularly after Day 4 . It is difficult, therefore, to explain the observations of Whitely et al. (1985) of concentrations of plasma relaxin of up to $8 \mathrm{ng} / \mathrm{ml}$ in response to suckling on Days 26 and 33 of lactation. The in-vitro results were consistent in indicating that the corpora lutea at this time would contain no immunoreactive cells and undetectable concentrations of relaxin ( $<30 \mathrm{ng}$ in total). Furthermore, the histological appearance of the corpora lutea and the lack of measurable progesterone secretion at Day 21 confirmed that they were in an advanced state of regression both structurally and functionally. It has also been reported that relaxin occurs in the theca tissue of ovarian follicles (Evans et al., 1983; Bagnell et al., 1987), particularly during the later stages of follicle development. However, the ovaries recovered from the suckled sows in the present study did not contain any large follicles, and this, with the finding that concentrations of circulating plasma relaxin were all virtually below detection, confirms that the theca tissue was not a major 
source of relaxin in this study. Other extra-ovarian sources of relaxin have been reported, namely human amnion, chorion and decidua (Bryant-Greenwood et al., 1987), but there was no evidence in the present experiment of any major extra-ovarian source of relaxin. It is possible that some of these non-luteal tissues produce either a prohormone or a different form of relaxin which crossreacts with some of the available relaxin antisera, but not all. This could explain the apparent discrepancy between the present results and some of those reported by others.

The finding that the corpora lutea recovered from zero-weaned sows were significantly heavier and contained and secreted more progesterone than those from Day 4 suckled sows is of interest. The tissue from both groups of sows was recovered 4 days after parturition, and so variation in age cannot account for these differences. Zero weaning of sows has been reported to result in an apparently normal oestrus and ovulation within 2 weeks of delivery or in the development of ovarian cysts and prolonged oestrus (Peters et al., 1969; Kunavongkrit et al., 1983). More recently, it has been shown that follicular development was enhanced in zero-weaned, compared with suckling sows, and that this was due to the release of low concentrations of LH in an episodic manner, which was subsequently inhibited in the other sows by suckling (De Rensis, 1989). It is possible, therefore, that these episodes of $\mathrm{LH}$ were also sufficient to maintain the corpora lutea partially in the zero-weaned sows. Also, exogenous oxytocin has been shown to inhibit progesterone secretion by porcine luteal cells from cyclic animals (Przala et al., 1986), which would affect the suckled sows rather than the zero-weaned sows. In the present study, no significant effect of oxytocin in vitro was determined, but this is likely to have been due to the regressive nature of the tissue which was incubated.

The results show that relaxin concentrations were very low during established lactation and were not stimulated by suckling in vivo or exogenous oxytocin in vitro. Furthermore, the corpora lutea recovered from zero-weaned and lactating sows showed no immunoreactivity and negligible concentration of relaxin or progesterone in the tissues, and had the appearance and function typical of regressing tissue. Therefore, it is concluded that during lactation the old corpus luteum of pregnancy is not capable of releasing relaxin in response to suckling in vivo or to oxytocin treatment in vitro.

This work was supported by the Agricultural and Food Research Council and by the Medical Research Council.

\section{References}

Afele, S., Bryant-Greenwood, G.D., Chamley, W.A. \& Dax, E.M. (1979) Plasma relaxin immuno activity in the pig at parturition and during nuzzling and suckling. J. Reprod. Fert. 56, 451-457.

Anderson, L.L., Ford, J.J., Melampy, R.M. \& Cox, D.F. (1973) Relaxin in porcine corpora lutea during pregnancy and after hysterectomy. Am. J. Physiol. 225, $1215 \cdots 1219$.

Anderson, L.L., Adair, V., Stromer, M.H. \& McDonald, W.G. (1983) Relaxin production and release after hysterectomy in the pig. Endocrinology 113, 677-686.

Bagnell, C.A., Frando, L.B., Downey, B.R., Tsang, B.K. \& Ainsworth, L. (1987a) Localization of relaxin in pig follicles during preovulatory development. J. Reprod. Fert. 69, 677-683.

Bagnell, C.A., McMurtry, J.P., Baker, N.K., Timtim, J.K. \& Bryant-Greenwood, G.D. ( 1987 b) Detection of relaxin by immunohistochemistry in the corpus luteum during lactation. Biol. Reprod. 37, 1317-1325.

Bagnell, C.A., Tashime, L., Tsark, W., Ali, S.M., McMurtry, J.P. (1990) Relaxin gene expression in the sow corpus luteum during the cycle, pregnancy and lactation. Endocrinology 126, 2514-2520.

Bryant-Greenwood, G.S., Rees, M.C.P. \& Turnbull, A.C. (1987) Immunohistochemical localization of relaxin, prolactin and prostaglandin synthase in human amnion, chorion and decidua. $J$. Endocr. 114, 49 I -496 .

Denning-Kendell, P.A., Guldenaar, S.E.F. \& Wathes, D.C. (1989) Evidence for a switch in the site of relaxin production from small theca-derived cells to large luteal cells during early pregnancy in the pig. $J$. Reprod. Fert. 85, 261-271.

De Rensis, F. (1989) Reproductive physiology of the early post-partum sow. M. Phil. thesis, University of Nottingham.

Evans, G., Wathes, D.C., King, G.J., Armstrong, D.T. \& Porter, D.G. (1983) Changes in relaxin production by the theca during the preovulatory period of the pig. $J$. Reprod. Fert. 69, 677-683.

Gordon, W.L. \& Sherwood, O.D. (1982) Evidence that LH from the maternal pituitary gland may promote Downloaded from Bioscientifica.com at 04/26/2023 08:47:43AM via free access 
ante partum release of relaxin, luteolysis and birth in rats. Endocrinology 111, 12991305.

Hunter, M.G. \& Wiesak, T. (1990) Evidence and implications of follicular heterogeneity. J. Reprod. Fert. Suppl. 40, 163 177.

Hunter, M.G., Southee, J.A. \& Lamming, G.E. (1988) Function of abnormal corpora lutea in vitro after GnRH-induced ovulation in the anoestrous ewe. $J$. Reprod. Fert. 84, 139-148.

Kendall, J.Z., Richards, G.E. \& Shih, L.N. (1983) Effect of haloperidol, suckling oxytocin and hand milking on plasma relaxin and prolactin concentrations in cyclic and lactating pigs. J. Reprod. Fert. 69, $271-277$.

Kunavongkrit, A., Kindahl, H., Einarsson, S. \& Edqvist, L.E. (1983) Clinical and endocrinological studies in primiparous zero-weaned sows. Zbl. Vet. Med. A. 30, 607-615.

Kwok, S.C.M., McMurtry, J.P. \& Bryant, G.S. (1976) The relationship between relaxin and prolactin immunoactivity in various reproductive states: physical, chemical and immuno-biological studies. In Growth Hormone and Related Peptides, pp. 414421. Eds A. Pecile \& A. Muller. Exerpta Medica, Amsterdam.

Nara, B.S., Ball, G.D., Rutherford, J.E., Sherwood, O.D. \& First, N.L. (1982) Release of relaxin by a nonluteolytic dose of prostaglandin $F 2 \alpha$ in pregnant swine. Biol. Reprod. 27, 1190-1194.

O'Byrne, E.M., Tabachnick, M., Anderson, L.L. \& Steinetz, B.G. (1989) Characterisation of the circulating form of porcine relaxin: biological activity and terminal amino acids. Endocrinology 124, 2920 2927.

Peters, J.B., Short, R.E., First, N.L. \& Casida, L.E. (1969) Attempts to induce fertility in the post partum sow. J. Anim. Sci. 29, 20-24.

Przala, J., Grazul, A., Wiesak, T., Muszynska, A. \& Rzasa, J. (1986) The effect of oxytocin and vasotocin upon progesterone, testosterone and estradiol $17 \beta$ secretion by the luteal cells from cyclic pigs. Exp. clin. Endocr. 85, 193-199.

Rao, C.V. \& Edgerton, L.A. (1984) Dissimilarity of corpora Jutea within the same ovaries or those from right and left ovaries of pigs during the oestrous cycle. $J$. Reprod. Fert. 70, 61-66.
Sherwood, O.D. \& O'Byrne, E.M. (1974) Purification and characterization of porcine relaxin. Arch. Biochem. Biophys. 160, 185-196.

Sherwood, O.D., Chang, C.C., Bevier, G.W. \& Dzuik, P.J. (1975) Radioimmunoassay of plasma relaxin levels throughout pregnancy and at parturition in the pig. Endocrinology 97, 834-837.

Sherwood, O.D., Crnekovic, V.E., Gordon, W.L. \& Rutherford, J.E. (1980) Radioimmunoassay of relaxin throughout pregnancy and during parturition in the rat. Endocrinology 107, 691-698.

Sherwood, O.D., Nara, B.S., Welk, F.A., First, N.L. \& Rutherford, J.E. (1981) Relaxin levels in the materna! plasma of pigs before, during and after parturition and before, during and after suckling. Biol. Reprod. 25, 65-71

Steinetz, B.G., Beach, V.L., Kroc, N.R., Stasilli, N.R., Nussbaum, R.E., Nemith, P.J. \& Dun, R.K. (1960) Bioassay of relaxin using a reference standard: a simple and reliable method utilizing direct measurement of interpubic ligament formation in mice. Endocrinology 67, 102-115.

Taverne, M., Bevers, M., Bradshaw, J.M.C., Dieleman, S.J., Willemse, A.H. \& Porter, D.G. (1982) Plasma concentrations of prolactin, progesterone, relaxin and oestradiol-17 $\beta$ in sows treated with progesterone, bromocriptine or indomethacin during late pregnancy. J. Reprod. Fert. 65, 85-96.

Taylor, M.J. \& Clark, C.L. (1987) Detection of relaxin release by porcine luteal cells using a reverse hemolytic plaque assay: effect of prostaglandins $E_{2}$ and $F_{2} \alpha$, human chorionic gonadotropin and oxytocin. Biol. Reprod. 37, 377-384.

Walsh, J.R. \& Niall, H.D. (1980) Use of an octa decylsilica purification method minimises proteolysis during isolation of porcine and rat relaxins. Endocrinology 107, 12581260.

Wathes, D.C., King, G.J., Porter, D.G. \& Wathes, C.M. (1989) Relationship between pre-partum relaxin concentrations and farrowing intervals in the pig. $J$. Reprod. Fert. 87, 383-390.

Whitely, J., Willcox, D.L., Harmann, P.E., Yamamoto, S.Y. \& Bryant-Greenwood, G.D. (1985) Plasma relaxin levels during suckling and oxytocin stimulation in the lactating sow. Biol. Reprod. 33, 705--714.

Received 29 October 1990 